\title{
Clinical significance of Catheter-Associated Urinary Tract Infection (CAUTI) in Intensive Care Units: Three Year Experience at a Single Centre
}

\author{
Sunil Basukala1, Punit Yadav', Arindam Chatterjee ${ }^{2}$, Rakesh Kumar Ranyal ${ }^{2}$ and \\ Manish Baidya ${ }^{3}$
}

${ }^{1}$ Department of Surgery, Nepalese Army Institute of Health Science, Shree Birendra Hospital, Chhauni, Kathmandu, Nepal

${ }^{2}$ Department of Hospital Administration, Armed Forces Medical College, Pune, India

${ }^{3}$ Research Associate, Kathmandu University, Nepal

\begin{abstract}
Introduction: Catheter Acquired Urinary Tract Infection (CAUTI) is one of the most common Health Care Acquired Infections (HCAI); most of these infections are attributable to use of an indwelling urethral catheter. The aim of this study was to investigate patients with catheter-associated urinary tract infection over three years at a single hospital's Intensive Care Unit (ICU) and to identify meaningful risk factors and causative organisms.

Methods: A retrograde analysis was performed on patients with indwelling catheters in ICU of Armed Forces Medical College, Pune, India. CAUTI was defined as isolated bacterial growth of 100,000 colonyforming units or more either 48 hours after transfer to the ICU if a urinary catheter was placed before the transfer or 48 hours after insertion if the catheter was inserted in the ICU. Only the patients whose culture results were negative before ICU admission were included.

Result: Among 350 samples collected in medical and surgical ICU, 38 patients (10.85\%) had CAUTI. Using multivariate logistic regression analysis, the study showed that those with diabetes were 4.51 ( $\mathrm{p}<$ 0.001) times likely to have occurrences of CAUTI than those without and also showed an increased incidence of CAUTI $>1.19$ fold $(\mathrm{p}<0.01)$ among patient with longer duration of an indwelling catheter.

Conclusions: CAUTI is a preventable HCAI and thus the risk factors and causative organisms contributing to its development in the management of ICU patients must be considered to prevent the occurrence of UTIs in this setting.
\end{abstract}

Key words: Biofilm; Health Care Acquired Infection (HCAI); Intensive care units (ICU)

Correspondence: Sunil Basukala, Department of Surgery, Nepalese Army Institute of Health Science, Shree Birendra Hospital, Chhauni, Kathmandu, Nepal. Email: anyurysm@gmail.com

DOI: $10.3126 / \mathrm{mjsbh.v20i2.36502}$

Submitted on: 2021-04-18

Accepted on: 2021-06-10 


\section{INTRODUCTION}

Hospitalisation poses numerous hazards to patients that has been known for decades. ${ }^{1}$ HealthcareAssociated Infections (HCAI) represents a major preventable patient safety issue. One fourth of HCAI involve patients in Intensive Care Units (ICU), and nearly $70 \%$ are due to microorganisms that are multi-drug resistant, indicating an escalating public health crisis. Three types of infection account for $80 \%$ of all HCAI in the ICU: Catheter Associated Urinary Tract Infection (CAUTI), bloodstream infection and pneumonia (usually ventilator-associated, VAP). ${ }^{2-5}$ These remain as leading causes of nosocomial infections, with significant morbidity, mortality, and additional hospital costs accounting approximately $16 \%$ of ICU patients. ${ }^{6-8}$

The term CAUTI refers to patients who develop a urinary tract infection (UTI) with an indwelling urinary catheter in place or within 48 hours of the catheter removal and are considered complicated UTIs. ${ }^{9}$ The risk of an infection is almost $3-10 \%$ per day of catheterisation. ${ }^{10,11}$ Studies have shown that an estimated $17 \%$ to $69 \%$ of CAUTIs may be preventable with recommended infection control measures, which means that up to 380,000 infections and 9,000 deaths related to CAUTIs per year could be prevented. ${ }^{12,13}$ Several preventable risk factors such as length of ICU stay, prior use of antibiotic, severity score at admission, and duration of catheterisation acts as a potential factors for development of CAUTI which should be identified among the patients admitted in ICU. ${ }^{14,15}$ The aim of this research was to study the prevalence of CAUTI among the patients admitted in the adult ICU of a tertiary care hospital and to identify its potential risk factors and causative organisms.

\section{METHODS}

A retrospective review of the prospectively collected data over the period of three years was performed on patients with indwelling catheters between April 2013 and March 2016 in Armed Forces Medical College (AFMC), Pune, India. The protocol for this research was approved by the ethics committee of Armed Forces Medical College, Pune, India. CAUTI was defined as isolated bacterial growth of 100,000 colonyforming units or more - either 48 hours after transfer to the ICU if a urinary catheter was placed before the transfer, or 48 hours after insertion if the catheter was inserted in the ICU. Only patients whose culture results were negative prior to ICU admission were included. To differentiate between asymptomatic bacteriuria (ASB) and UTI, patient records were investigated for the presence of fever (temperature greater than $37.8^{\circ} \mathrm{C}$ ) at the time of positive urine culture results; those results exhibiting ASB were excluded. The control group consisted of ICU patients with indwelling catheters who had negative urine culture results before and after ICU transfer (48 hours post-transfer to discharge from the ICU). The demographic and clinical data were collected. Only latex catheters were used for urinary catheters, and careful attention was given to the drainage system, disposing of the urine accumulated in the collection bag and keeping the system closed. Urine collection was performed with a sterile syringe after wiping the catheter end with a boric sponge. Bacteria in the collected urine were identified by using an ATB kit. No medicated catheters were used among the patients for the study. Statistical analysis was performed by using the IBM SPSS ver. 24.0. Univariate analysis was conducted to determine potential risk factors for bacteriuria occurrence. The $\chi^{2}$ or Fisher's exact test was used for qualitative variables, and Student's t-test was used for quantitative variables. The required significance level was set at a p-value less than 0.05 .

\section{RESULT}

There were total 350 patients with indwelling urinary catheters in hospital's medical and surgical ICU between April 2013 to March 2016; 38 $(10.85 \%)$ had CAUTI as defined in this study and while 312 met the criteria for the control group. Among them 202 admissions were in (Medical Intensive Care Unit) MICU and 148 admissions were in SICU (Surgical Intensive Care Unit). The number of CAUTI was $26(72.2 \%)$ in MICU and $12(33.3 \%)$ in SICU. Of the 350 eligible patients, $58(70.8 \%)$ were males and $102(29.1 \%)$ were females. In terms of age, 58 patients $(16.5 \%)$ were between 18 and 25 years of age, 43 (12.2\%) were between 26 and 35 years, $71(20.2 \%)$ were between 35 and 45 years and $178(50.85 \%)$ were more than 45 years. There were 244 catheterised patients 
Table 1. Characteristics of patients and results of a chi-square test between the CAUTI and control groups

\begin{tabular}{|c|c|c|c|c|c|c|}
\hline SN & Characteristics & & $\begin{array}{l}\text { CAUTI } \\
(\mathrm{N}=38)\end{array}$ & $\begin{array}{l}\text { Control } \\
(\mathbf{N}=312)\end{array}$ & $\begin{array}{c}\text { Total } \\
(\mathrm{N}=350)\end{array}$ & P - value \\
\hline 1 & Sex & $\begin{array}{l}\text { Male } \\
\text { Female }\end{array}$ & $\begin{array}{l}25(65.7 \%) \\
13(34.2 \%)\end{array}$ & $\begin{array}{r}223(71.4 \%) \\
89(28.5 \%)\end{array}$ & $\begin{array}{l}248(68.8 \%) \\
102(28.3 \%)\end{array}$ & $<0.05$ \\
\hline 2 & Age in years & $\begin{array}{l}18-25 \\
25-35 \\
36-45 \\
>45\end{array}$ & $\begin{array}{r}3(7.89 \%) \\
3(7.89 \%) \\
3(7.89 \%) \\
29(76.3 \%)\end{array}$ & $\begin{array}{r}55(17.6 \%) \\
40(12.8 \%) \\
68(21.7 \%) \\
149(47.7 \%)\end{array}$ & $\begin{array}{r}58(\%) \\
43(\%) \\
71(\%) \\
278(\%)\end{array}$ & $>0.05$ \\
\hline 3 & Intensive care Unit & $\begin{array}{l}\text { MICU } \\
\text { SICU }\end{array}$ & $\begin{array}{l}26(68.4 \%) \\
12(31.5 \%)\end{array}$ & $\begin{array}{l}176(56.4 \%) \\
136(43.5 \%)\end{array}$ & $\begin{array}{l}202(57.7 \%) \\
148(42.2 \%)\end{array}$ & $>0.05$ \\
\hline 4 & Diabetes & $\begin{array}{l}\text { Yes } \\
\text { No }\end{array}$ & $\begin{array}{r}36(94.7 \%) \\
02(5.2 \%)\end{array}$ & $\begin{array}{l}208(66.6 \%) \\
104(33.3 \%)\end{array}$ & $\begin{array}{l}244(70 \%) \\
106(30 \%)\end{array}$ & 0.37 \\
\hline 5 & Renal failure & $\begin{array}{l}\text { Yes } \\
\text { No }\end{array}$ & $\begin{array}{l}11(29 \%) \\
27(71 \%)\end{array}$ & $\begin{array}{r}20(6.4 \%) \\
292(93.6 \%)\end{array}$ & $\begin{array}{r}31(8.5 \%) \\
319(91.5 \%)\end{array}$ & $>0.05$ \\
\hline 6 & Antibiotics & $\begin{array}{l}\text { Yes } \\
\text { No }\end{array}$ & $\begin{array}{r}33(86.8 \%) \\
05(13.15 \%)\end{array}$ & $\begin{array}{r}285(90.1 \%) \\
27(6.9 \%)\end{array}$ & $\begin{array}{r}318(90.8 \%) \\
32(9.2 \%)\end{array}$ & $>0.05$ \\
\hline 7 & Place of catheterization & $\begin{array}{l}\text { Operating room } \\
\text { A and E } \\
\text { General ward } \\
\text { ICU }\end{array}$ & $\begin{array}{r}02(4.9 \%) \\
15(11.1 \%) \\
09(8.1 \%) \\
12(19 \%)\end{array}$ & $\begin{array}{r}39(95.1 \%) \\
120(88.9 \%) \\
102(91.1 \%) \\
51(81.0 \%)\end{array}$ & $\begin{array}{r}41(11.7 \%) \\
135(38.5 \%) \\
111(31.7 \%) \\
63(18 \%)\end{array}$ & $>0.05$ \\
\hline 8 & $\begin{array}{l}\text { Duration of } \\
\text { catheterization }\end{array}$ & $\begin{array}{l}<3 \text { days } \\
3 \text { - } 7 \text { days } \\
>7 \text { days }\end{array}$ & $\begin{array}{r}6(9.2 \%) \\
18(7.9 \%) \\
14(24.1 \%)\end{array}$ & $\begin{array}{r}59(90.8 \%) \\
209(92.1 \%) \\
44(75.9 \%)\end{array}$ & $\begin{array}{r}65(18.5 \%) \\
227(64.8 \%) \\
58(16.5 \%)\end{array}$ & $<0.05$ \\
\hline 9 & Length of stay in ICU & $\begin{array}{l}<7 \text { days } \\
>7 \text { days }\end{array}$ & $\begin{array}{r}24(8.2 \%) \\
14(24.1 \%)\end{array}$ & $\begin{array}{r}268(91.8 \%) \\
44(75.9 \%)\end{array}$ & $\begin{array}{r}292(83.4 \%) \\
58(16.6 \%)\end{array}$ & $<0.05$ \\
\hline
\end{tabular}

(46.3\%) who had diabetes and $106(53.7 \%)$ did not and among them $36(94.7 \%)$ patients developed CAUTI while two (5.2\%) patients who were nondiabetic also developed CAUTI while 11 (29\%) with renal failure developed CAUTI while 27 (71\%) patients without renal failure developed CAUTI. Thirty three patients $(86.8 \%)$ had used antibiotics before catheter insertion, whereas five $(13.15 \%)$ had no prior antibiotic exposure. A catheter was inserted in the operating room in two patients $(4.9 \%)$, in the emergency room in 15 patients $(11.1 \%)$, in general wards in nine patients $(8.1 \%)$, and in the ICU in 12 patients $(19 \%)$. The mean duration of having an inserted catheter was 14.19 days [standard deviation (SD), 13.72]. Highest incidence of CAUTI was seen among 14 (24.1\%) patients catheterised for more than seven days Table 1.

The difference in the presence of diabetes between the groups was statistically significant $(\mathrm{p}<0.001)$; it was also statistically significant $(\mathrm{p}<0.001)$ by use of a Fisher's exact test (a nonparametric test). In the CAUTI group, $94.7 \%$ of the patients had diabetes, and $5.2 \%$ did not; in the control group, $66.6 \%$ of the patients had diabetes and $33.3 \%$ did not. The difference in the durations of having an indwelling catheter and of ICU admission was statistically significant between the two groups $(p$ $<0.01$ ); this difference was also shown on the Mann-Whitney test $(\mathrm{p}<0.001)$, which is a nonparametric test. The duration of having an indwelling catheter was longer in CAUTI patients (mean $\pm \mathrm{SD}, 27.72 \pm 20.65$ ) than in the control group (mean $\pm \mathrm{SD}, 15.80 \pm 11.84$ ), and the length of ICU admission was also longer in the CAUTI group (mean $\pm \mathrm{SD}, 23.08 \pm 18.77$ ) than in the control group (mean $\pm \mathrm{SD}, 14.94 \pm 11.88$ ). Other factors (i.e., sex, age, location of catheter insertion, presence of renal failure and prior use of antibiotics) was not significantly different between the groups $(p>0.05)$. The results of univariate and multivariate logistic regression of the factors contributing to CAUTI occurrence i.e., sex, age, recent surgery, presence of diabetes, presence of renal failure, use of antibiotics, location of catheter 
Table 2. Results of univariate and multivariate analysis of factors contributing to CAUTI occurrence

\begin{tabular}{|c|c|c|c|c|c|c|}
\hline \multirow[t]{2}{*}{ SN } & \multirow[t]{2}{*}{ Characteristics } & & \multicolumn{2}{|c|}{ Univariate analysis } & \multicolumn{2}{|c|}{ Multivariate analysis } \\
\hline & & & OR $(95 \% \mathrm{CI})$ & P-value & OR $(95 \% \mathrm{CI})$ & P - value \\
\hline 1 & Sex & $\begin{array}{l}\text { Male } \\
\text { Female }\end{array}$ & $\begin{array}{r}1.00 \text { (referent) } \\
1.67(1.00-3.57)\end{array}$ & 0.051 & $\begin{array}{r}1.00 \text { (referent) } \\
2.56(0.96-3.93)\end{array}$ & 0.076 \\
\hline 2 & Age in years & $\begin{array}{l}18-25 \\
25-35 \\
36-45 \\
>45\end{array}$ & $\begin{array}{r}1.00 \text { (referent) } \\
0.51(0.17-2.21) \\
0.67(0.21-2.64) \\
1.47(0.41-5.01)\end{array}$ & 0.568 & $\begin{array}{r}1.00 \text { (referent) } \\
0.36(0.05-2.21) \\
0.97(0.18-2.64) \\
0.91(0.41-4.01)\end{array}$ & 0.87 \\
\hline 3 & $\begin{array}{l}\text { Intensive care } \\
\text { Unit }\end{array}$ & $\begin{array}{l}\text { MICU } \\
\text { SICU }\end{array}$ & $\begin{array}{r}1.00 \text { (referent) } \\
0.97(0.71-1.64)\end{array}$ & 0.68 & $\begin{array}{r}1.00 \text { (referent) } \\
0.26(0.05-1.21)\end{array}$ & 0.71 \\
\hline 4 & Diabetes & $\begin{array}{l}\text { Yes } \\
\text { No }\end{array}$ & $\begin{array}{r}3.52(1.81-7.01) \\
1.00(\text { referent })\end{array}$ & 0.001 & $\begin{array}{r}4.11(0.21-1.17) \\
1.00 \text { (referent) }\end{array}$ & 0.012 \\
\hline 5 & Renal failure & $\begin{array}{l}\text { Yes } \\
\text { No }\end{array}$ & $\begin{array}{r}0.98(0.49-1.94) \\
1.00(\text { referent })\end{array}$ & 0.943 & $\begin{array}{r}1.74(0.67-4.02) \\
1.00 \text { (referent) }\end{array}$ & 0.67 \\
\hline 6 & Antibiotics & $\begin{array}{l}\text { Yes } \\
\text { No }\end{array}$ & $\begin{array}{r}0.77(0.70-2.11) \\
1.00(\text { referent })\end{array}$ & 0.51 & $\begin{array}{r}0.87(0.30-1.19) \\
1.00 \text { (referent) }\end{array}$ & 0.67 \\
\hline 7 & $\begin{array}{l}\text { Place of } \\
\text { catheterization }\end{array}$ & $\begin{array}{l}\text { Operating room } \\
\text { A \& E } \\
\text { General ward } \\
\text { ICU }\end{array}$ & $\begin{array}{r}0.51(0.17-2.11) \\
0.87(0.40-2.11) \\
1.71(0.411-2.70) \\
1.00 \text { (referent) }\end{array}$ & $\begin{array}{l}0.411 \\
0.711 \\
0.714\end{array}$ & $\begin{array}{l}0.17(0.04-0.07) \\
0.31(0.11-1.05) \\
0.37(0.07-1.09)\end{array}$ & $\begin{array}{r}0.27 \\
0.062 \\
0.97\end{array}$ \\
\hline 8 & $\begin{array}{l}\text { Duration of } \\
\text { catheterisation }\end{array}$ & $\begin{array}{l}<3 \text { days } \\
3-7 \text { days } \\
>7 \text { days }\end{array}$ & $\begin{array}{r}1.00 \text { (referent) } \\
4.18(0.21-1.17) \\
0.81(0.40-2.11)\end{array}$ & $\begin{array}{l}0.011 \\
0.012\end{array}$ & $\begin{array}{r}1.00 \text { (referent) } \\
2.52(1.81-3.01) \\
1.61(0.411-1.70)\end{array}$ & $\begin{array}{l}0.87 \\
0.34\end{array}$ \\
\hline 9 & $\begin{array}{l}\text { Length of stay } \\
\text { in ICU }\end{array}$ & $\begin{array}{l}<7 \text { days } \\
>7 \text { days }\end{array}$ & $\begin{array}{r}3.78(0.21-1.27) \\
1.00(\text { referent })\end{array}$ & 0.91 & $\begin{array}{r}2.22(1.31-2.78) \\
1.00(\text { referent })\end{array}$ & 0.87 \\
\hline
\end{tabular}

insertion, duration of indwelling catheter are shown in Table 2.

Table 3. Microbiological organisms in development of CAUTIs in ICUs

\begin{tabular}{|l|l|r|}
\hline S. no & Pathogens & $\begin{array}{r}\text { No. of isolated } \\
(\mathrm{N}=38)\end{array}$ \\
\hline 1 & Escherichia coli & $16(40 \%)$ \\
2 & Enterococcus spp & $07(20 \%)$ \\
3 & Staphylococcus aureus & $05(12 \%)$ \\
5 & Candida spp & $05(12 \%)$ \\
6 & Pseudomonas aeruginosa & $03(7 \%)$ \\
\hline
\end{tabular}

In the univariate logistic regression analysis, those with diabetes were 3.52 [95\% confidence interval (CI), 1.81-7.01; $\mathrm{p}<0.001]$ times as likely to have occurrences of CAUTI, with a 1.05 fold $(95 \% \mathrm{CI}$, 1.03-1.08; $<$ 0.001) higher incidence of increased duration of catheter placement in the ICU. Thus, among the patients with CAUTI, the presence of diabetes, the duration of the indwelling catheter, and the duration of the indwelling catheter in the ICU were identified as having significant effects on CAUTI occurrence. Other factors did not appear to have a significant effect. Using multivariate logistic regression analysis, those with diabetes were 4.11 [95\% CI, $(0.21-1.17) ; \mathrm{p}<0.001]$ times likely to have occurrences of CAUTI than those without diabetes and also had a 1.10-fold (95\% CI, 1.03 to 
$1.16 ; \mathrm{p}<0.01)$ longer duration of an indwelling catheter. Other factors did not have significant effects on the incidence of CAUTI.

In the urine culture results, among the 38 patients with CAUTI, Escherichia coli was the most common bacterium grown; it was identified in 16 patients (40\%), followed by Enterococcus spp. in seven patients (20\%), Staphylococcus aureus in five patients (12\%), Candida spp. in five patients $(12 \%)$, Pseudomonas aeruginosa in three patients (7\%), and Klebsiella pneumoniae in two patients (5\%) Table 3.

\section{DISCUSSION}

The Centres for Disease Control and Prevention (CDC) defines Healthcare Associated Infections (HAIs) as those that develop during hospitalisation but are neither present nor incubating upon the patient's admission to the hospital; generally, for those infections that occur more than 48 to 72 hours after admission and within 10 days after hospital discharge. ${ }^{16,17}$ CAUTI is one of the commonest HCAIs; $70-80 \%$ of these infections are attributable to use of an indwelling urethral catheter. ${ }^{18-20}$ UTI in hospitalised patients is often overlooked or regarded as an unavoidable temporary and insignificant incident. ${ }^{21,22}$ The urinary tract is the commonest site of nosocomial infection and most of these infections follow instrumentation of the urinary tract, mainly urinary catheterisation and is a frequent cause of significant morbidity, sepsis and death. ${ }^{23}$

This study only defined symptomatic UTIs requiring treatment as CAUTI; those uninfected before ICU admission who developed CAUTI within 48 hours of transfer to the ICU were designated as CAUTI occurring in the ICU during patient selection. ${ }^{24-25}$ The CDC definition of nosocomial infection was used as a reference in developing these definitions. ${ }^{9-11}$ Several risk factors have been cited to be associated with CAUTI. In this study, risk factors such as duration of catheterisation, diabetes and length of ICU stay were found to be significantly associated with acquisition of infection. Increased duration of catheterisation was identified as a significant factor associated with acquiring CAUTI in this study and in several other studies. ${ }^{20,21}$ Other risk factors such as age, gender, presence of renal failure among the patients, use of antibiotics and place of catheterisation were not statistically significant in this study which was similar to other studies. ${ }^{26-28}$ This study also showed a significant association between duration of catheter insertion and CAUTI as the Pearson Chi-square value is $<0.05$ (i.e. 0.002 ). We found that $24.1 \%$ of patients with catheter for more than seven days developed CAUTI against $8.2 \%$ of patients who had catheter for less than seven days. Thus the odd of patients with catheter for more than seven days to develop CAUTI is 0.281 times higher than those with less than seven days. This finding of ours is similar to other similar studies. ${ }^{11,22}$

According to the guidelines on Diagnosis, Prevention, and Treatment of CAUTI in adults by the Infectious Diseases Society of America in 2009, indications for urinary catheter insertion are described as follows: clinically significant urinary retention, urinary incontinence, accurate urine output monitoring required, and patient unable or unwilling to collect urine. ${ }^{23}$ This study also identified diabetes as an important risk factor in the development of CAUTI, and diabetes as a factor in the development of UTIs has been confirmed in numerous other studies. ${ }^{24}$ Patients with diabetes, impaired granulocyte function, increased adherence of uropathogens to bladder epithelial cells, and the effects of glycosuria on the growth of uropathogens in diabetic patients contribute to a higher UTI prevalence. ${ }^{29} \mathrm{Few}$ other studies documented the presence of diabetes as a risk factor and proposed two possibilities for why diabetic patients are at increased risk of acquiring infection: an increased prevalence of perineal colonisation by potential pathogens and an increased ability of the urine of some patients with diabetes to support microbial growth. These effects of diabetes promote the colonisation of uropathogens on the catheter surface when urinary catheters are indwelled and affect the synthesis of biofilms. Patients with diabetes, especially those admitted to the ICU with indwelling catheters, are more susceptible to the development of urosepsis. ${ }^{20-24}$ Hence, these patients require strict blood glucose monitoring to prevent CAUTI occurrence and progression. ${ }^{11}$ According to the 2006 to 2007 statistics from the NHSN, the pathogens identified (in the order of frequency) 
were E. coli (21.4\%), candida spp. (21.0\%), enterococcus spp. (14.9\%), P. aeruginosa (10.0\%), K. pneumoniae (7.7\%), and enterobacter spp. (4.1\%); this grouping is similar to the culture results from this study and few other studies. ${ }^{11}$

\section{CONCLUSIONS}

CAUTI remains a leading cause of nosocomial infections, with significant morbidity, mortality, and additional hospital costs. However, UTI in hospitalised patients is often overlooked or regarded as an unavoidable temporary and insignificant incident. UTI following instrumentation are generally assumed to be benign. Risk factors such as duration of catheterisation and diabetes should be considered among the patient admitted in ICU to reduce the incidence of CAUTI. In addition to these, strict attention to infection control practices can also decrease CAUTI. Our study underlines the necessity to reduce the duration of catheterisation to avoid the occurrence of bacteriuria in ICU patients. Indeed, among the independent risk factors that we isolated the duration of catheterisation was the only variable that ICU physicians can determine.

\section{ACKNOWLEDGEMENT}

We would like to acknowledge patient of AFMC and medical professionals / staffs of Medical and Surgical ICU department for assistance with patient evaluation.

To cite this article: Basukala S, Yadav P, Chatterjee A, Ranyal RK, Baidya M. Clinical significance of CatheterAssociated Urinary Tract Infection (CAUTI) in Intensive Care Units: Three Year Experience at a Single Centre. MJSBH. 2021;20(2):116-22.

Conflict of Interest: None declared

\section{REFERENCES}

1. Leape LL, Woods DD, Hatlie MJ, Kizer KW, Schroeder SA, Lundberg GD. Promoting patient safety by preventing medical error. JAMA. 1998 Oct 28;280(16):1444-7. DOI: 10.1001/jama.280.16.1444

2. Safdar N, Abad C. Educational interventions for prevention of healthcare-associated infection: a systematic review. Crit Care Med. 2008;36(3):933-40. DOI: 10.1097/ccm.0b013e318165faf3

3. Laupland KB, Bagshaw SM, Gregson DB, Kirkpatrick AW, Ross T, Church DL. Intensive care unit-acquired urinary tract infections in a regional critical care system. J Crit Care. 2005;9(2):60. DOI:10.1186/cc3023

4. Saint S, Meddings JA, Calfee D, Kowalski CP, Krein SL. Catheter-associated urinary tract infection and the Medicare rule changes. Ann Intern Med. 2009;150(12):877-84. DOI:10.7326/0003-4819-150-12-200906160-00013

5. Wachter RM, Foster NE, Dudley RA. Medicare's decision to withhold payment for hospital errors: the devil is in the details. Jt Comm J Qual Patient Saf. 2008;34(2):116-23. DOI: 10.1016/s1553-7250(08)34014-8

6. Al-Hazmi H. Role of duration of catheterisation and length of hospital stay on the rate of catheter-related hospitalacquired urinary tract infections. Res Rep Urol. 2015;7:41. DOI:10.2147/rru.s75419

7. Reilly L, Sullivan P, Ninni S, Fochesto D, Williams K, and Fetherman B. Reducing Foley Catheter Device Days in an Intensive Care Unit. AACN Adv Crit Care. 2006;17:272-283. DOI: 10.4037/15597768-2006-3006

8. Andreessen L, Wilde MH, Herendeen P. Preventing catheter-associated urinary tract infections in acute care: the bundle approach. J Nurs Care Qual. 2012;27(3):209-17. DOI:10.1097/ncq.0b013e318248b0b1

9. Tambyah PA, Maki DG. Catheter-associated urinary tract infection is rarely symptomatic: a prospective study of 1497 catheterized patients. Arch Intern Med. 2000;160(5):678-82. DOI:10.1001/archinte.160.5.678

10. Djordjevic Z, Jankovic S, Gajovic O, Djonovic N, Folic N, Bukumiric Z. Hospital infections in a neurological intensive care unit: incidence, causative agents and risk factors. J Infect Dev Ctries. 2012;6(11):798-805. DOI: 10.3855/jidc.2659 
11. Warren JW. Catheter-associated urinary tract infections. Int J Antimicrob Agents 2001;17:299-303. DOI: 10.1016/ s0924-8579(00)00359-9.

12. Gould CV, Umscheid CA, Agarwal RK, Kuntz G, Pegues DA. Healthcare Infection Control Practices Advisory Committee. Guideline for prevention of catheter-associated urinary tract infections 2009. Infect Control Hosp Epidemiol. 2010 Apr;31(4):319-26. DOI:10.1086/651091

13. Leone M, Albanèse J, Garnier F, Sapin C, Barrau K, Bimar M-C, et al. Risk factors of nosocomial catheterassociated urinary tract infection in a polyvalent intensive care unit. Intensive Care Med. 2003;29(7):1077-80. DOI: $10.1007 / \mathrm{s} 00134-003-2080-9$

14. Datta P, Rani H, Chauhan R, Gombar S, Chander J. Health-care-associated infections: Risk factors and epidemiology from an intensive care unit in Northern India. Indian J Anaesth. 2014;58(1):30. DOI: $10.4103 / 0019-5049.126785$

15. ULU A, Kurtaran B, Kibar F, Karakoc E, Aksu HSZ, Tasova Y. Invasive device-associated nosocomial infections of a teaching hospital in Turkey; four years' experience. TJMS. 2011;41(1):137-47. DOI:10.5812/hepatmon.25639

16. Lujan M, Gallego M, Rello J. Healthcare-associated infections. A useful concept? Curr Opin Crit Care. 2009;15(5): 419-24. DOI:10.1097/mcc.0b013e32832e9956

17. Hansen S, Sohr D, Geffers C, Astagneau P, Blacky A, Koller W, et al. Concordance between European and US case definitions of healthcare-associated infections. Antimicrob Resist Infect Control. 2012;1(1):28. DOI: $10.1186 / 2047-2994-1-28$

18. Rosenthal VD, Maki DG, Salomao R, Moreno CA, Mehta Y, Higuera F, et al. Device-associated nosocomial infections in 55 intensive care units of 8 developing countries. Ann Intern Med. 2006;145(8):582-91. DOI: 10.7326/0003-4819-145-8-200610170-00007

19. Richards MJ, Edwards JR, Culver DH, Gaynes RP. Nosocomial infections in combined medical-surgical intensive care units in the United States. Infect Control Hosp Epidemiol. 2000;21(8):510-5. DOI:10.1086/501795

20. Aly NYA, Al-Mousa HH, Al Asar ESM. Nosocomial infections in a medical-surgical intensive care unit. Med Princ Pract. 2008;17(5):373-7. DOI:10.1159/000141500

21. Hooton TM, Bradley SF, Cardenas DD, Colgan R, Geerlings SE, Rice JC, et al. Diagnosis, prevention, and treatment of catheter-associated urinary tract infection in adults: 2009 International Clinical Practice Guidelines from the Infectious Diseases Society of America. Clin Infect Dis. 2010;50(5):625-63. DOI:10.1086/650482

22. Rezai MS, Bagheri-Nesami M, Nikkhah A. Catheter-related urinary nosocomial infections in intensive care units: An epidemiologic study in North of Iran. Caspian J Intern Med. 2017;8(2):76. DOI: 10.22088/cjim.8.2.76.

23. Linda AMHW, Pam H. Preventing Catheter-Associated Urinary Tract Infections in Acute Care: The Bundle Approach. J Nurs Care Qual. 2012;27:8. DOI: 10.1097/ncq.0b013e318248b0b1

24. Isa M, Ismail H, Allamin I, Shettima A, Mustapha A. Prevalence Of Urinary Tract Infection Among Primary School Children In Maiduguri, Borno State, Nigeria. IJE. 2013;2(1):9-15. DOI:10.3126/ije.v2i1.9203

25. Morgan DJ, Meddings J, Saint S, Lautenbach E, Shardell M, Anderson D, et al. Does nonpayment for hospitalacquired catheter-associated urinary tract infections lead to overtesting and increased antimicrobial prescribing? Clin Infect Dis. 2012;55(7):923-9. DOI:10.1093/cid/cis556

26. Bagshaw SM, Laupland KB. Epidemiology of intensive care unit-acquired urinary tract infections. Curr Opin Infect Dis. 2006;19(1):67-71. DOI:10.1097/01.qco.0000200292.37909.e0

27. Kunin CM. Urinary-catheter-associated infections in the elderly. Int J Antimicrob Agents. 2006;28(1):78-81. DOI: 10.1016/j.ijantimicag.2006.05.013

28. Tew L, Pomfret I, King D. Infection risks associated with urinary catheters. Nurs Stand. 2005;20(7):55-61. DOI: 10.7748/ns2005.10.20.7.55.c3987

29. Clec'h C, Schwebel C, Français A, Toledano D, Fosse JP, MaïtéGarrouste-Orgeas M, et al. Does CatheterAssociated Urinary Tract Infection Increase Mortality in Critically Ill Patients? Infect Control Hosp Epidemiol. 2007;28(12):1367-73. DOI:10.1086/523279 